\title{
ANALISIS PENGARUH DESENTRALISASI DAN SISTEM AKUNTANSI MANAJEMEN TERHADAP KINERJA MANAJERIAL \\ ( Studi Kasus Pada PT. Charoen Pokhpand Indonesia Tbk. Cabang Makassar )
}

\author{
Asriani Hasan' ${ }^{1)}$, Randi ${ }^{2)}$ \\ 12) Prodi Akuntansi, Fakultas Ekonomi dan Bisnis,Universitas Muhammadiyah Makassar \\ Jalan Sultan Alauddin No.259, Kota Makassar 90221 \\ 1) asriani.hasan@unismuh.ac.id \\ ${ }^{2)}$ randirasyid1196@gmail.com
}

Diterima: 23 Maret 2020. Disetujui: 30 Mei 2020. Dipublikasikan: Juni 2020

\begin{abstract}
Abstrak
Penelitian ini bertujuan untuk mengetahui pengaruh desentralisasi dan sistem akuntansi manajemen terhadap kinerja manajerial di PT. Charoen Pokhpand Indonesia Tbk Cabang Makassar. Penelitian ini menerapkan metode kuantitatif dengan menggunakan analisis regresi linier berganda. Data dalam penelitian ini merupakan data yang diperoleh dari responden PT. Charoen Pokhpand Indonesia Tbk. Cabang Makassar dengan cara pengambilan sampel sebanyak 60 responden. Pada penelitian ini diperoleh nilai konstanta sebesar 27,604. Nilai signifikansi untuk pengaruh desentralisasi $(X 1)$ terhadap kinerja manajerial $(Y)$ yaitu sebesar 0,003 $<0,005$ dengan nilai $t_{\text {hitung }} 3,141>t_{\text {tabel }} 2,002$ dan nilai koefisiennya sebesar 0,264. Selanjutnya,nilai signifikansi pengaruh sistem akuntansi manajemen $(X 2)$ terhadap kinerja manajerial $(Y)$ yaitu sebesar $0,010<0,005$ dengan nilait hitung $_{2,673}>t_{\text {tabel }} 2,002$ dan nilai koefisen regresi sebesar 0,199. Temuan dari penelitian ini menunjukkan bahwa kinerja manajerial dipengaruhi oleh desentralisasi dan sistem akuntansi manajemen. Dapat disimpulkan bahwa desentralisasi dan sistem akuntansi manajemen baik digunakan dalam pengambilan keputusan untuk meningkatkan kinerja pada perusahaan.
\end{abstract}

Kata kunci:Desentralisasi,Sistem Akuntansi Manajemen,dan Kinerja Manajerial

\begin{abstract}
This research aims to determine the influence of decentralization and accounting management system against managerial performance at PT. Charoen Pokhpand Indonesia Tbk Makassar Branch. This research implements quantitative methods using multiple linear regression analyses. The data in this research is data obtained from respondents PT. Charoen Pokhpand Indonesia Tbk. Makassar Branch by sampling 60 respondents. The granting of the questionnaire was used as a method for collecting data. In this study obtained a constant value of 27.604. Value of significance for decentralized influence $(X 1)$ to managerial performance $(Y)$ of $0,003<$ 0,005 with value $t_{\text {value }} 3,141>t_{\text {table }} 2,002$ and coefficient value of 0.264 . Next, Value of significance for decentralized influence $(X 2)$ to managerial performance $(Y)$ of $0,010<0,005$ with value $t_{\text {value }} 2,673>t_{\text {table }} 2,002$ and regression coefficient value of 0,199 . Findings from this study suggest that managerial performance is influenced by decentralization and accounting management systems. It can be concluded that decentralization and management accounting systems are both used in decision making to improve performance on the company.
\end{abstract}

Keywords: Decentralizations, Management Accounting Systems, Managerial Performance 


\section{PENDAHULUAN}

Setiap pemilik perusahaan tentunya menginginkan perusahaannya dapat berkembang. Salah satu hal yang dapat menunjang berkembangnya suatu perusahaan adalah kinerja atau kemampuan kerja yang baik oleh setiap stakeholder. Kinerja merupakan hasil secara kualitas dan kuantitas yang diraih oleh seorang pegawai dalam melaksanakan fungsinya sesuai dengan tanggung jawab yang diberikan kepadanya. Setiap anggota dalam gaya organisasi atau perusahaan yang memiliki motivasi tujuan yang baik makan akan memiliki kemampuan kerja atau kinerja yang baik pula (Sari, 2016). Oleh karena itu, kemampuan kerja pada suatu perusahaan adalah hal yang penting untuk diperhatikan oleh seorang pimpinan perusahaan supaya dapat meningkatkan kemampuan kerja karyawannya sehingga dapat bersaing dengan perusahaan yang lain. Hal ini tentunya tidak terlepas dari gaya kepemimpinan.

Gaya kepemimpinan harus mengutamakan prestasi yang dapat meningkatkan kinerja manajerial. (Rante et al., 2014) berpendapat bahwa gaya kepemimpinan mempunyai pengaruh signifikan terhadap kinerja manajerial. Menurut (Moheri \& Arifah, 2015), kinerja manajerial adalah salah satu faktor utama yang mampu meningkatkan efektivitas organisasi atau perusahaan. Artinya, kinerja manajerial merupakan pekerjaan karyawan yang dilaksanakan dalam kurun waktu tertentu dengan standar, target atau kriteria yang telah ditetapkan dan disepakati bersama. Selain itu, sistem akuntansi perusahaan juga harus mendapatkan perhatian.

Sistem akuntansi saat ini sudah sangat berkembang, dimana para manajer perusahaan mengutamakan sistem akuntansi manajemen dalam melakukan fungsi perencanaan, pengendalian, penilaian atau evaluasi, perbaikan berkelanjutan, serta memberikan informasi untuk pengambilan keputusan (Butarbutar et al., 2017). Perusahaan merancang sistem akuntansi manajemen untuk menolong organisasi yang terlibat melalui para manajernya antara lain perencanaan, pengorganisasian, pengarahan, dan pengambilan keputusan. Satu diantara produk sistem akuntansi manajemen yakni adanya informasi manajemen yang mempunyai peranan dalam meramalkan akibat yang mungkin terjadi atas berbagai alternatif tindakan yang dapat dilakukan pada berbagai aktivitas atau kegiatan.

Penelitian (Gul \& Chia, 1994) secara empiris menyatakan bahwa karakteristik informasi akuntansi manajemen bergantung pada variabel konseptual organisasi yakni desentralisasi. Terdapat dua sub sistem kontrol yang akan mempunyai pengaruh positif terhadap kinerja manajerial yakni sistem informasi manajemen dan desentralisasi. Jika ada interaksi yang cocok maka pengaruh positif itu terjadi. Pengaruh interaksi antara karakteristik setiap informasi sistem akuntansi manajemen dengan desentralisasi akan semakin positif apabila kondisi tingkat desentralisasi tinggi.

Penelitian ini sejalan dengan penelitian yang dilakukan oleh (Qibtiyah \& Ananda, 2018) dengan judul "Pengaruh Desentralisasi dan Sistem Akuntansi Manajemen Terhadap Kinerja Manajerial pada Politeknik Kesehatan Siteba". Hasil penelitian tersebut menunjukkan bahwa secara parsial variabel desentralisasi berpengaruh positif terhadap kinerja manajerial. Hal ini terjadi karena desentralisasi mampu meningkatkan kinerja akibat adanya pendelegasian wewenang yang diberikan kepada manajer tingkat bawah sedangkan sistem akuntansi manajemen tidak memiliki pengaruh signifikan terhadap kinerja manajerial.

Perbedaan kedua penelitian ini terletak pada objeknya. Penelitian sebelumnya menggunakan lembaga Politeknik Kesehatan Siteba sedangkan penelitian ini memilih perusahaan untuk dijadikan objek yaitu PT. Charoen Pokhpand Indonesia Tbk. Cabang Makassar. PT. Charoen Pokhpand Indonesia Tbk. Cabang Makassar dipilih sebagai objek penelitian karena perusahaan tersebut merupakan salah satu perusahaan pakan ternak yang terbesar di Indonesia yang memiliki banyak anak perusahaan dan jumlah karyawan yang cukup besar. Hal tersebut mendukung penelitian yang dilakukan untuk melihat pengaruh desentralisasi dan sistem akuntansi manajemen terhadap kinerja manajerial.

Tujuan penelitian ini yaitu untuk mengetahui pengaruh desentralisasi dan sistem akuntansi manajemen terhadap kinerja manajerial. Penelitian ini dianggap penting untuk dilakukan agar perusahaan mengetahui hal-hal yang dapat meningkatkan kinerja karyawan seluruh divisi dan 
mendapatkan masukan atau referensi terkait hal-hal yang mempengaruhi sistem kerja dan penentuan kebijakan dalam perusahaan.

\section{TINJAUAN PUSTAKA}

Dalam penelitian (Juniarti \& Evelyne, 2003) mengatakan bahwa ada beberapa ukuran yang dapat memberikan penilaian kinerja berdasarkan perspektif non keuangan, yaitu :

a. Kemampuan manajer dalam melakukan perencanaan

Perencanaan yang baik dapat meningkatkan fokus dan fleksibilitas manajer dalam menangani pekerjaannya. Artinya fokus dan flesibilitas dua hal yang utama bagi manajer untuk menghadapi daerah persaingan yang tinggi dengan penuh semangat. Kekuatan manajer dalam melakukan perencanaan menjadi salah satu indikator untuk menilai kinerja.

b. Kinerja manajer dapat dinilai dari kesanggupan mereka untuk mencapai apa yang telah direncanakan. Mempunyai sasaran khusus, melibatkan partisipan, realistik, menantang dan memiliki rentang waktu yang jelas.

c. Kiprah manajer diluar perusahaan

Intensitas manajer sebagai wakil perusahaan untuk berhubungan baik dengan pihak luar menyatakan keyakinan perusahaan terhadap manajer tersebut. Keyakinan tersebut tidak serta merta muncul begitu saja,tetapi muncul atas kinerja yang baik dari manajer itu sendiri. Peranan manajer sebagai wakil perusahaan dapat menjadi salah satu indikator kinerja manajer.

Dari pendapat tersebut dapat disimpulkan bahwa penilaian kinerja berdasarkan perspektif non keuangan itu sangat penting untuk diperhatikan dalam suatu perusahaan karena memiliki peranan penting dalam pengambilan keputusan khususnya juga memperhatikan 3 poin penting yang dikemukakan oleh peneliti sebelumnya. Kemampuan manajer dalam melakukan perencanaan merupakan langkah awal yang dilakukan oleh perusahaan untuk dapat meningkatkan fokus para manajer dalam mengerjakan suatu kegiatan atau aktivitas perusahaan. Langkah awal ini dapat mendukung manajer untuk menyusun aktivitas yang akan dilakukan perusahaan. Selanjutnya, jika perencanaan yang dibuat oleh seorang sudah fixed atau sesuai dengan apa yang telah disusun, maka seorang manajer mampu menilai kemampuan disetiap divisi pada suatu perusahaan dengan tujuan tertentu dari perusahaan dalam rentang waktu yang telah ditetapkan sebelumnya. Seorang manajer mampu meningkatkan kinerja perusahaan juga harus memiliki relasi diluar perusahaan untuk meyakinkan bahwa kinerja perusahaan tersebut baik dan dapat berkembang.

Penelitian (Rante et al., 2014) mengemukakan beberapa hal antara lain:

a. Desentralisasi mempunyai pengaruh terhadap kinerja manajerial. Hal ini menerangkan bahwa adanya pelimpahan wewenang dan tanggung jawab dalam pengambilan keputusan berkenaan dengan aktivitas sehari hari yang diberikan manajemen puncak kepada manajemen tingkat menengah yang berupaya untuk meningkatkan kinerjanya.

b. Sistem akuntansi manajemen dapat memediasi pengaruh gaya kepemimpinan terhadap kinerja manajerial. artinya, kinerja manajerial dapat meningkat jika informasi yang ada disajikan dalam bentuk laporan sesuai dengan model keputusan dari penerapan gaya kepemimpinan yang telah dibangun.

Menurut (Setyolaksono, 2011) desentralisasi merupakan kebijakan-kebijakan dari setiap perusahaan yang sifatnya berdiri sendiri atau independen. Dengan kata lain, setiap perusahaan dapat memberikan wewenang pada masing-masing divisi dalam perusahaan untuk menyusun dan melakukan kegiatan. Adanya wewenang setiap divisi dapat mendorong motivasi karyawan untuk meningkatkan kinerja. Dengan adanya sistem desentralisasi setiap kegiatan maka pengawasan dan penilaian lebih mudah untuk dilakukan. Wewenang yang dimaksud adalah hak untuk memberikan tugas,sedangkan tanggung jawab adalah menyelesaikan tugas yang telah diberikan. Artinya, semakun tingkat desentralisasi maka semakin tinggi wewenang manajer dalam mengambil keputusan secara otonom.

Dari beberapa pendapat tersebut dapat disimpulkan bahwa desentralisasi adalah rangkaian konsep dan yang menjadi dasar suatu perusahaan yang sifatnya independen. Artinya setiap perusahaan dapat memberikan wewenang ke setiap divisi dalam perusahaan untuk bertanggung 
jawab dalam menyusun dan melaksanakan aktivitasnya. Maka dari itu desentralisasi disetiap perusahaan sangat diperlukan utnuk memotivasi karyawan dalam meningkatkan kinerjanya. Dengan kata lain, semakin tinggi tingkat desentralisasi yang diterapkan maka semakin tinggi tanggung jawab dari seorang manajer disetiap divisi dalam melaksanakan pengawasan dan penilaian dari kegiatan yang dilakukan.

Pendapat (Solechan \& Setiawati, 2009) perushaan mendesain sistem akuntansi manajemen untuk membantu organisasi melalui para manajer dalam hal perencanaan, pengorganisasian, pengarahan dan pengambilan keputusan. Manajer membutuhkan informasi yang berkualitas dan relevan untuk mendukung keputusan yang berkualitas.

Dari pendapat peneliti sebelumnya dapat disimpulkan bahwa sistem akuntansi manajemen juga merupakan variabel penting yang dapat menjadi mediasi pengaruh gaya kepemimpinan terhadap kinerja manajerial. Jadi kinerja manajerial akan meningkat apabila informasi yang ada diolah menjadi laporan sesuai dengan pengambilan keputusan dari gaya kepemimpinan yang diterapkan. Selain itu, sistem akuntansi manajemen juga memiliki peran yang mendasar dalam mendukung keputusan dan mengatasi masalah.

\section{METODE PENELITIAN}

Jenis penelitian ini adalah penelitian kuantitatif. Sumber data yang digunakan adalah data primer. Data primer merupakan data yang diperoleh langsung di lapangan oleh peneliti sebagai objek penulisan. Sumber data tersebut diperoleh dari jawaban atas kuisioner yang dibagikan kepada 60 responden. Responden dalam penelitian ini yaitu seluruh karyawan dan pimpinan perusahaan PT. Charoen Pokhpand Indonesia Tbk. Cabang Makassar yang terdiri atas divisi produksi, divisi pemasaran, divisi finance and accounting, divisi sumber daya manusia ( Human Resource Development ), divisi feedtech, dan divisi penjualan (sales). Sampel dalam penelitian ini diambil secara acak sederhana (simple random sampling).

Kuisioner yang digunakan adalah model kuisioner dari penelitian (Setyolaksono, 2011) yang berjudul "Pengaruh Desentralisasi dan Sistem Akuntansi Manajemen Terhadap Kinerja Manajerial ( Studi Kasus Pada Industri Es Balok di Kota Semarang )" dengan menggunakan teknik skoring atas jawaban dari pertanyaan-pertanyaan pada kuisioner. Skala pengukuran menggunakan skala Likert dengan 5 pilihan tingkat yaitu sangat setuju (SS) dengan poin 5, setuju (S) dengan poin 4, Netral (N) dengan poin 3, Tidak Setuju (TS) dengan poin 2, hingga sangat tidak setuju (STS) dengan poin 1. Kuisioner dibawa langsung oleh peneliti ke perusahaan dan diberikan kepada bagian Sumber Daya Manusia ( Human Resource Development ).

Mengukur valid tidaknya dari suatu kuisioner dengan tujuan mengetahui kesamaan data yang dikumpulkan dengan data sesungguhnya digunakan pengujian validitas. Selanjutnya uji reabilitas digunakan untuk mengetahui seberapa jauh hasil pengukuran tetap konsisten apabila dilakukan lebih dari dua kali terhadap gejala yang sama dengan menggunakan alat pengukuran yang sama.ssi

Penelitian ini menggunakan regresi linier berganda sebagai analisis data. Metode pengolahan data diawali dengan menyebarkan kuisioner kepada responden. Selanjutnya, kuisioner yang diperoleh diverifikasi sesuai dengan kebutuhan penelitian. Langkah selanjutnya mengelompokkan data atas jawaban-jawaban dari kuisioner, dihitung dan dijumlahkan lalu diolah menggunakan SPSS 25.

\section{PEMBAHASAN}

Hasil penelitian Analisis Pengaruh Desentralisasi dan Sistem Akuntansi Terhadap Kinerja Manajerial dapat dilihat pada tabel di bawah ini.

Tabel 1. Analisis Pengaruh Desentralisasi dan Sistem Akuntansi Manajemen Terhadap Kinerja manajerial

\begin{tabular}{|l|c|c|c|c|}
\hline \multicolumn{1}{|c|}{ Variabel } & $\begin{array}{c}\text { Koefisien } \\
\text { Regresi } \\
(\mathrm{B})\end{array}$ & $\mathrm{t}$ Hitung & $\begin{array}{c}\text { Signifikan } \\
\mathrm{t}\end{array}$ & Keterangan \\
\hline Konstanta & 27,604 & 8,122 & 0.000 & \\
\hline Desentralisasi $\left(X_{1}\right)$ & 0,264 & 3,141 & 0,003 & Signifikan \\
\hline Sistem Akuntansi Manajemen $\left(X_{2}\right)$ & 0,199 & 2,675 & 0,010 & Signifikan \\
\hline
\end{tabular}


Persamaan regresi linier berganda pada tabel 1 adalah sebagai berikut:

$$
Y=27,604+0,264 X_{1}+0,199 X_{2}
$$

Apabila desentralisasi dan sistem akuntansi manajemen menghasilkan nol, Artinya kinerja manajerial akan menjadi sebesar 27,604. Jika ada peningkatan sebesar 1 poin desentralisasi akan diikuti peningkatan poin pada kinerja manajerial sebesar 0,264 apabila sistem akuntansi manajemen dianggap tetap. Jika ada kenaikan 1 poin sistem akuntansi manajemen akan diikuti kenaiakan kinerja manajerial sebesar 0,199 jika desentralisasi dianggap tidak berubah.

Nilai signifikansi untuk pengaruh desentralisasi $(X 1)$ terhadap kinerja manajerial $(Y)$ yaitu sebesar 0,003 $<0,005$ dengan nilai $t_{\text {hitung }} 3,141>t_{\text {tabel }} 2,002$ dan nilai koefisiennya sebesar 0,264 . Hasil tersebut menunjukkan bahwa desentralisasi (X1) mempunyai pengaruh terhadap kinerja manajerial $(Y)$. Artinya, desentralisasi mempunyai pengaruh yang signifikan terhadap kinerja manajerial pada PT. Charoen Pokhpand Tbk. Cabang Makassar. Hal tersebut berhubungan dengan peranan pemberian wewenang dan tanggung jawab kepada manajer. Dapat disimpulkan apabila tingkat desentralisasi tinggi maka akan mempunyai pengaruh terhadap kinerja manajer. Hal ini menguatkan pendapat peneliti (Dwinarian et al., 2017) bahwa desentralisasi mempunyai pengaruh parsial terhadap kinerja manajerial.

Selanjutnya, nilai signifikansi pengaruh sistem akuntansi manajemen $(X 2)$ terhadap kinerja manajerial $(Y)$ yaitu sebesar $0,010<0,005$ dengan nilai $t_{\text {hitung }} 2,673>t_{\text {tabel }} 2,002$ dan nilai koefisen regresi sebesar 0,199. Dengan kata lain, sistem akuntansi manajemen mempunyai pengaruh positif terhadap kinerja manajerial. Hal ini menunjukkan bahwa sistem akuntansi manajemen mempunyai pengaruh terhadap kinerja manajerial pada PT. Charoen Pokhpand Indonesia Tbk. Cabang Makassar. Artinya, sistem akuntansi manajemen berpegang penting dalam sistem pengendalian di suatu organisasi khususnya untuk proses perencanaan organisasi. Hal tersebut menunjukkan bahwa pihak manajemen sebaiknya mempraktikkan sistem akuntansi manajemen secara benar. Hal tersebut dapat dilihat dengan semakin kompleksnya pekerjaan pada suatu perusahaan sehingga dengan adanya sistem akuntansi manajemen yang baik dapat membantu pekerjaan untuk meningkatkan kinerja perusahaan. Hasil penelitian ini sejalan dengan hasil penelitian yang dilakukan oleh (Dwinarian et al., 2017) yang menyatakan bahwa sistem akuntansi manajemen mempunyai pengaruh terhadap kinerja manajerial.

\section{KESIMPULAN}

Berdasarkan hasil penelitian, disimpulkan bahwa secara signifikan kinerja manajerial dipengaruhi oleh desentralisasi. Artinya, semakin baik praktik atau penerapan desentralisasi dalam perusahaan maka akan berpengaruh terhadap kinerja manajerial pada perusahaan. Hal ini menunjukkan bahwa desentralisasi dapat memudahkan dalam pengumpulan dan pemanfaatan informasi, manajemen pusat tidak terhalang dalam perumusan perencanaan, dan proses pengambilan keputusan strategis, dan dapat meningkatkan daya saing.

Kinerja manajerial dipengaruhi sistem akuntansi manajemen. Artinya semakin meningkat sistem akuntansi manajemen yang diterapkan atau dipraktikkan di suatu perusahaan, maka semakin meningkat kinerja manajerial. Dapat disimpulkan bahwa penelitian ini dapat dimanfaatkan oleh perusahaan untuk menjalankan desentralisasi khususnya dalam pengambilan keputusan yang berhubungan dengan kebijakan operasional. Selanjutnya, perlunya sistem akuntansi manajemen mampu membantu perusahaan dalam menentukan kebijakan-kebijakan yang dapat meningkatkan kinerja manajerial dari suatu perusahaan.

Saran dari penelitian ini yaitu dapat berkontribusi untuk lebih lanjut dengan menggunakan metode analisis data yang lebih baik dengan menambahkan beberapa variabel tambahan yang menunjukkan pengaruh terhadap kinerja manajerial. Adapun keterbatasan penelitian yang dilakukan antara lain : 
1. Peneliti tidak memberikan perbedaan untuk karakteristik organisasi responden

2. Peneliti hanya menggunakan metode analisis regresi linier berganda yang memiliki keterbatasan untuk menganalisa dalam melakukan pengujian hungan antara variabel-variabel pada penelitian.

\section{DAFTAR PUSTAKA}

Butarbutar, J. D., Karamoy, H., \& Tirayoh, V. Z. (2017). 312 3. 12(1), 187-193.

Dwinarian, F., Asnawi, M., \& Sanggenafa, M. (2017). Pengaruh Desentralisasi dan Sistem Akuntansi Manajemen Terhadap Kinerja Manajerial (Studi Kasus Di Perbankan Kota Jayapura dan Kabupaten Jayapura). Jurnal Akuntansi \& Keuangan Daerah, 12(1), 39-55.

Gul, \& Chia, Y. . (1994). The Effect of Management Accounting System,Perceived Environmental Uncertainty and Decentralization on Managerial Performance:" A Tes of Three-way Interaction". Accounting,Organisations and Society, 19, 413-416.

Juniarti, \& Evelyne. (2003). Hubungan Karakteristik Informasi Yang Oleh Sistem Informasi Akuntansi Manajemen Terhadap Kinerja Manajerial Pada Perusahaan-Perusahaan Manufaktur Di Jawa Timur. Nazaruddin.

Moheri, Y., \& Arifah, A. D. (2015). Pengaruh Partisipasi Anggaran terhadap Kinerja Manajerial. EKOBIS, 16, 86-93.

Qibtiyah, M., \& Ananda, F. (2018). Pengaruh Desentralisasi dan Sistem Akuntansi Manajemen Terhadap Kinerja Manajerial Pada Politeknik Kesehatan Siteba.

Rante, A., Rosidi, \& Djamhuri, A. (2014). Sistem Akuntansi Manajemen, Gaya Kepemimpinan, dan Desentralisasi sebagai Determinan Kinerja Manajerial. Jurnal Akuntansi Multiparadigma, 5(1). https://doi.org/10.18202/jamal.2014.04.5005

Sari, R. N. I. (2016). Peningkatan Kinerja Pegawai melalui Kepuasan Kerja dan Disiplin Kerja. Jurnal Pendidikan Manajemen Perkantoran, 1, 204-2014. http://ejournal.upi.edu/index.php/jpmanper/article/view/00000

Setyolaksono, B. (2011). Pengaruh Desentralisasi dan Sistem Akuntansi Manajemen Terhadap Kinerja Manajerial (Studi Kasus Pada Industri Es Balok di Kota Semarang). Universitas Negeri Semarang.

Solechan, A., \& Setiawati, I. (2009). Pengaruh Karakteristik Sistem Akuntansi Manajemen dan Desentralisasi Sebagai Variabel Moderating Terhadap Kinerja Manajerial. Jurnal Riset Ekonomi Dan Manajemen, Vol.4 No.1.

\section{Biodata Penulis 1}

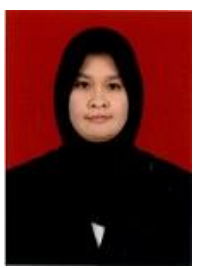

Nama Asriani Hasan,SE.,M.Sc. tempat dan tanggal lahir di Bulukumba,16 Februari 1989. Kegiatan Saya yakni sebagai Dosen Tetap Yayasan pada Program Studi Akuntansi FEB Universitas Muhammadiyah Makassar. Prodi yang pernah Saya tempuh (S1) jurusan Akuntansi tahun 2007 Universitas Hasanuddin. Saya melanjutkan Program Magister (S2) Jurusan Matematika dengan Konsentrasi Matematika Keuangan tahun 2013 Universitas Gadjah Mada.

\section{Biodata Penulis 2}

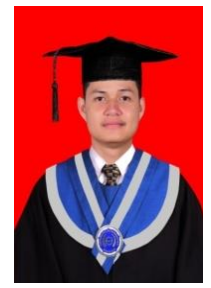

Randi lahir di Bittoengtanggal 30 November 1996. Penulisanak ke-3 dari 3 bersaudara. Peneliti sekarang bertempattinggal di Jalan ABDESIR Lorong 5 Kel.Tamamaung, Kec.Panakkukang, Kota Makassar. Pendidikan yang telah saya tempuh yakni SDN 133 Bittoeng, SMP Negeri 1 Duampanua lulus tahun 2012, SMA Negeri 2 Pinrang lulus tahun 2015. Tahun 2015 saya melanjutkan kuliah pada Program S1 Akuntansi Universitas Muhammadiyah Makassar. 